\title{
EDITORIAL
}

\section{Linguagem neutra: ofensa à língua portuguesa ou preconceito velado?}

Tempos bastante inusitados esse em que vivemos.

Uma sociedade que reconhecidamente mantem-se afastada, em sua imensa maioria, dos parâmetros mais elevados do ensino tem usado um elemento francamente formal como parâmetro a respaldar a negativa a uma tentativa de inclusão de grupos vulnerabilizados inseridos nas minorias sexuais. A educação continua sendo uma das mais vilipendiada das bases indissociáveis da constituição de uma sociedade cidadã. Mesmo com a clássica cantilena de todos os governantes e candidatos a cargos políticos de que a educação há de ser uma prioridade grassa em todo o território nacional, salvo raras e gloriosas exceções, um ensino que se mostra muito aquém daquele esperado e desejado.

O Brasil continua ostentando posições vergonhosas nas avaliações internacionais de estudantes como o PISA (Programa Internacional de Avaliação de Estudantes), com pontuação abaixo da média atingida por países da Organização para a Cooperação e Desenvolvimento Econômico (OCDE) em Leitura, Matemática e Ciências ${ }^{1}$.

Tais fatos, per si, são ensejadores de um infindável número de considerações no que concerne às consequências deles provenientes no que tange à forma como as questões atinentes à sexualidade são tratadas na sociedade brasileira, contudo o presente texto se dedica a tecer breves palavras quanto a discussão que envolve a utilização da linguagem neutra de gênero e as objeções a ela apresentadas.

O ponto fulcral da estranheza que nos move nesse escrito reside no fato de que a razão aduzida de forma recorrente para a oposição à utilização de expressões vinculadas a perspectivas de gênero seria o fato de que "a última flor do Lácio" não comportaria o uso de palavras como "ile", "elu", "todes", "todxs", "menines" ou quaisquer outras similares, e que seria imprescindível proteger a língua portuguesa e garantir que as crianças não sejam expostas a termos inexistente.

\footnotetext{
${ }^{1}$ https://www.oecd.org/pisa/publications/PISA2018_CN_BRA.pdf. Acesso em 13. dez.2021.
} 
Afirmações desse jaez apresentam contornos manifestos de tentativa de apagamento de um grupo vulnerabilizado. Inegavelmente tais palavras, como tantas outras corriqueiramente usadas, não estão oficialmente inseridas na língua portuguesa, contudo o que se questiona é se seria isso suficiente para se afastar a possibilidade de se laborar com uma linguagem mais inclusiva.

Aduzir a necessidade de plena atenção aos aspectos linguísticos formais como obstáculo para a utilização da linguagem neutra de gênero exsurge como uma tentativa de retirar da objeção formulada o verdadeiro caráter segregatório da qual ela se alimenta. Seriam esse altamente letrados(?) avessos à utilização de uma linguagem inclusiva mais uma vez contrários ao conhecimento constituído fora dos muros e arcadas dos prédios da academia?

O fato incontestável é que a dinamicidade inerente às línguas faladas não pode ser contida, ainda mais ante a atual realidade da sociedade da informação instalada. Aspectos culturais e sociais estão continuamente influenciando na maneira como as pessoas se comunicam, sendo impossível barrar a inserção na língua portuguesa de expressões novas.

A questão que se levanta está em se saber qual é exatamente a mola propulsora que leva à tentativa de se impedir que os neologismos fundados na linguagem neutra de gênero se estabeleçam, ainda mais ante a elaboração de proposições legislativas com o fulcro de proibi-las. A resposta é solar: seus motivos fundantes não são meramente linguisticos.

Segundo a agência de jornalismo independente Diadorim o uso do gênero neutro na língua portuguesa está presente em 34 projetos de lei espalhados por 19 estados brasileiros, visando impedir a variação gramatical para além do gênero masculino e feminino².

Tal sanha buscando a proteção da higidez da língua portuguesa não se faz presente contra outros "agressores" de sua integridade. O anglicismo, por exemplo, é uma realidade presente entre muitos daqueles que "torcem o nariz" para a linguagem neutra de gênero, inexistindo proposições para impedir a utilização de palavras como job para se referir a um trabalho, date para um encontro ou call para uma ligação.

2 https://www.adiadorim.org/post/brasil-tem-34-projetos-de-lei-estadual-para-impedir-uso-dalinguagem-neutra. Acesso em 13. dez. 2021. 
Ainda que incomode a muitos (como a mim mesmo) não se vê qualquer tipo de objeção oficial acerca da utilização de tais expressões. O incomodo queda-se como tal.

Em contexto similar se tem a amplamente difundida e utilizada linguagem oriunda do mundo virtual, profícua na criação de verbos (printar, shipar, logar, twittar, skipar), expressões (meme, emoji, Bitcoin) e atribuição de novos significados a palavras já existentes na língua portuguesa (baixar, avatar, viral), sem que isso dê azo a manifestações visando a vedação legal de que venham a ser usadas.

É patente que o português falado pela maioria da população brasileira está bastante distante dos aspectos formais da língua culta, além de se mostrar, em alguma medida, apartado do idioma falado nos demais países lusófonos. A unidade linguística sequer é vislumbrada dentro do território nacional, sendo um português (ou seria um brasileiro?) diferente se for considerada a idade, região, escolaridade ou grupo social daquele que o está manejando.

Se o real problema para a utilização da linguagem neutra de gênero fosse a existência de um "risco" de que crianças que viessem a aprender nas escolas palavras inexistentes na língua portuguesa tenho como certo que todo professor reuniria condições de levar aos seus alunos uma explicação que permitiria a eles entender qual é a exata razão da utilização do gênero neutro. Aos que não se sentissem ou fossem capacitados seria plenamente viável a promoção de atividades (ou alguns entenderiam melhor se fosse chamado de workshops?) com o fim de conferir-Ihes as ferramentas necessárias para tanto.

Bom seria se a preocupação com a educação do povo brasileiro fosse efetiva e não apenas de ocasião ou camuflada.

Imperioso se pontuar que no caso específico da linguagem neutra de gênero a questão lastreia-se em um parâmetro que não se faz presente em vários outros neologismos aqui trazidos que é a necessidade de inclusão de uma minoria sexual, resguardando a plena incidência do preceito nuclear da dignidade da pessoa humana.

A questão da dignidade humana há sempre de prevalecer e a inclusão há de ser um critério prioritário na condução da vida em sociedade.

Bastante plausível que a explicação de conceitos e ideias simples como a 
da utilização de linguagem neutra de gênero possa ser de grande valia para que se consiga disseminar na sociedade o entendimento de que a questão é séria e que exclusões de natureza sexual já causaram (e continuam causando) muitas feridas que poderiam ser sanadas simplesmente com uma visão de acolhida mínima àqueles que são segregados.

Característico se perceber que ordinariamente as vozes que bradam pela proteção da língua portuguesa são aquelas que nem sempre se valem da linguagem escorreita. Muitos ouvem músicas repletas de ofensas ao padrão culto sem que isso os mova numa cruzada para a proibição da reprodução das canções ou adequação das letras para que não se corra o risco de que as crianças "aprendam errado" ou se deparem com "palavras que não existem".

Evidente que não se está a pugnar por tal tipo de atitude vez que entendemos o imenso valor da cultura popular, oriunda das ruas e da vivência das pessoas. Apenas se faz tal provocação para que se reflita sobre qual o real motivo de uma súbita armada com o fim de proteger a língua portuguesa.

Muito provavelmente são as mesmas pessoas que ficam/ficariam profundamente ofendidas quando por qualquer motivo são chamadas equivocadamente por um nome próprio distinto do seu. Imagine se fosse por um nome de outro gênero... ${ }^{3}$

Se o uso de linguagem neutra de gênero for capaz de reduzir a segregação sofrida por parte da população brasileira entendo já ser argumento suficiente para se defender a sua implementação. Trata-se de uma mudança simples, que não vai inviabilizar a utilização da língua portuguesa, tampouco a comunicação das pessoas, além de ter o condão de tornar a sociedade melhor e mais cidadã para um grupo vulnerabilizado.

Aparenta ser bastante evidente que muito dessa refração de alguns assenta-se no mesmo espectro do preconceito existente na seara da identidade de gênero em que muitos "se negam a aceitar" a transição realizada por algumas pessoas, não Ihes conferindo tratamento segundo seu gênero de pertencimento,

${ }^{3}$ Leandro Reinaldo da Cunha. O esvaziamento do preceito do nome social diante das atuais decisões dos Tribunais Superiores. Revista dos Tribunais vol. 1011, São Paulo: Editora Revista dos Tribunais, 2020, p. 71. 
tampouco referindo-se a elas pelo nome escolhido.

Acredito que a oposição a uma proposição que vise garantir efetivo acesso a cidadania a um maior número de pessoas, mormente por inexistir a imposição de qualquer perda ou sacrifício para o restante da sociedade, sequer poderia ser objeto de qualquer sorte de objeção.

Dadas as devidas proporções e distinções, estaríamos nós diante de uma nova batalha como a entabulada outrora com relação ao "pretuguês" defendido por Lélia Gonzalez, considerando que ambas as questões se encontram num lugar de reconhecimento e afirmação de identidade? Numa analogia, poderíamos falar em um "neutroguês"?

Inquestionavelmente são questões que precisam ser pontuadas.

Há ainda outros pontos a serem suscitados. Ainda que se estivesse diante da proteção dos alicerces fundantes da língua portuguesa, essa visão haveria de prevalecer ante à dignidade da pessoa humana?

A resposta é clara: Não.

Seria aa língua portuguesa mais valiosa que o dever de inclusão de todas pessoas?

Indiscutivelmente, não.

A dignidade da pessoa humana, a acolhida e a empatia não são preceitos mais valiosos?

Sim. E muito.

É simples e não custa nada pensar na mitigação da dor alheia. Respeitar os grupos entendidos como minoritários, bem com seus direitos fundamentais é atender aos parâmetros mais nucleares de qualquer estado democrático de direito.

Que sejamos uma sociedade que acolha e respeite a todos, todas, todes ou todxs. Não importa seu pensamento íntimo sobre o tema, apenas tente poderar que esse simples ato usar a linguagem neutra de gênero pode mudar a vida de alguém.

Linguagem neutra de gênero. Por que não?

\section{Leandro Reinaldo da Cunha}

Editor Científico

Revista Direito e Sexualidade (RevDirSex)

e-mail: leandro.reinaldo@ufba.br 